\title{
Response Analysis of Deep Foundation Excavation and Dewatering on Surface Settlements
}

\author{
Xian Li, ${ }^{1}$ Tingguo Zhou, ${ }^{1}$ Yixian Wang $\mathbb{D}^{1},{ }^{1}$ Junling Han, ${ }^{1}$ Yanqiao Wang, ${ }^{1}$ Fang Tong, \\ Delong $\mathrm{Li}^{2}{ }^{2}$ and Jinmei Wen ${ }^{3}$ \\ ${ }^{1}$ School of Civil Engineering, Hefei University of Technology, Hefei 230009, China \\ ${ }^{2}$ Nanjiang Hydrogeology and Engineering Geology Team of Chongqing Bureau of Geology and Minerals Exploration, \\ Chongqing 401146, China \\ ${ }^{3}$ No. 208 Hydrogeology and Engineering Geology Team of Chongqing Bureau of Geology and Minerals Exploration, \\ Chongqing Institute of Geological Hazard Prevention Engineering Exploration and Design, Chongqing 400700, China \\ Correspondence should be addressed to Yixian Wang; wangyixian2012@hfut.edu.cn
}

Received 7 August 2020; Revised 19 October 2020; Accepted 20 October 2020; Published 10 November 2020

Academic Editor: Zhi Cheng Tang

Copyright $\odot 2020$ Xian Li et al. This is an open access article distributed under the Creative Commons Attribution License, which permits unrestricted use, distribution, and reproduction in any medium, provided the original work is properly cited.

\begin{abstract}
Accurate prediction of surface settlements is a primary concern when deep excavations were carrying out under the water table in urban environments for the safety of the work site. The sedimentation deformation due to deep excavation of foundation pit and dewatering occurs as a result of coupling action of the two factors. The study is aimed at revealing the coupling ground response to the two factors and developing empirical correlations for estimating ground deformations. Taking a deep foundation pit of a metro station as an example, surface settlement estimations were calculated by analytical formulas and numerical models. The settlement results by analytical formulas under excavation and dewatering conditions were added linearly to the total settlements. And three-dimensional coupling numerical models were established by applying commercial software (GMS and MIDAS) to investigate the interaction impact of excavation and dewatering on the sedimentation deformation. Comparing with monitoring data, numerical simulation results match well with the monitoring data. Furthermore, an empirical surface subsidence correlation equation was developed by the polynomial fitting to illustrate the effect contribution on the total surface settlement of foundation excavation and dewatering.
\end{abstract}

\section{Introduction}

Deep underground constructions built below the water table are inevitable in the urban region with the continuous city development. Due to the influence of groundwater, foundation pit dewatering becomes an auxiliary project that must be carried out in the process of deep excavation. A major concern for the urban deep excavations is the induced deformations in the surrounding soil and the subsequent impact on adjacent structures [1-5]. Erroneous estimates of sedimentation deformations may result in either large construction costs due to excessive ground support or damage to the surrounding structures due to inadequate excavation support. The factors such as construction technique, dewatering, and soil type have significant influences on the predicted deformations $[6,7]$.

Most of the main theories about settlement caused by excavation are based on the total stress method proposed by Peck based on curve-fitting of an enormous amount of field monitoring results [8-11]. The monitoring data show that the calculation results underestimate the actual settlement. Differences between measurements and theoretical predictions could be attributed to the effect of dewatering. The dewatering process can cause the depressurization of aquifers triggering the changes in effective stresses. When water is extracted from an aquifer, the effective stresses on the soil mass within it increase causing land subsidence [12-15]. Significant results have been achieved in land subsidence research, but the main factors causing land 
subsidence are excavation and dewatering [16-18]. Based on the linear superposition of the settlement caused by excavation and dewatering, the total surface settlement can be simply obtained but the interaction between stress release and groundwater level drop is ignored.

Taking a deep foundation pit of a metro station as an example, this paper is aimed at investigating the interaction response to surface settlement of deep foundation and dewatering. The total linear superposition settlements were calculated by analytical formulas under excavation and dewatering conditions. And three-dimensional coupling numerical models were established by commercial software (GMS and MIDAS) to obtain the response on the groundwater level, effective stresses, and the displacement of excavation and dewatering. Then, the two predicted surface settlement results were compared with the monitoring data to verify the validity of the two methods.

\section{Materials}

2.1. Project Description. The metro station foundation pit is located at the area of central China with the size of $120 \mathrm{~m} \times 15 \mathrm{~m} \times 22.4 \mathrm{~m}($ length $\times$ width $\times$ depth $)$. There is a river that goes round the west and south side of the station foundation pit with the minimum distance of $24 \mathrm{~m}$. The main structure of the shield shaft section is only $4.5 \mathrm{~m}$ away from the river bank. On the northwest side of the foundation pit is a hotel named building 1 . The main building of this hotel has 29 floors, and the five-storey building is pile foundation with the minimum distance of 10.7 meters away from the foundation pit. And the southeast side is a shopping mall named building 2 with 18 floors and the minimum distance of 10 meters. Its foundations are all pile foundations. The northeast side is building 3 with 6 floors. The location of the engineering site is shown in Figure 1.

The metro station foundation pit is mainly located in the alluvial-diluvial silty clay, silty soil, and fine sand layer with poor stability. The possibility of liquefaction exists in the fine sand layer, which has certain influence on the working process. The detailed geological profile of the site is shown in Figure 2.

The deep foundation excavation process was divided into five stages, namely, stage I, stage II, stage III, stage IV, and stage $V$, each with an excavation depth of $1.4 \mathrm{~m}, 2.7 \mathrm{~m}, 4.5 \mathrm{~m}$, $6.4 \mathrm{~m}$, and $7.4 \mathrm{~m}$, respectively. Each excavation floor level was $24.1 \mathrm{~m}, 21.4 \mathrm{~m}, 16.9 \mathrm{~m}, 10.6 \mathrm{~m}$, and $3.2 \mathrm{~m}$. The foundation pit dewatering was carried out along with the excavation stage, ensuring that the groundwater table was $0.5 \mathrm{~m}$ below the bottom of the foundation pit. The initial groundwater level was $23 \mathrm{~m}$. Foundation pit dewatering was not required during stage I of foundation excavation because the bottom of the foundation pit is higher than the groundwater level. The dewatering process started from stage II of foundation excavation which was divided into four stages of foundation dewatering.

2.2. Monitoring of Settlements. Before the construction process of the station foundation pit, pumping wells were set parallel along the side line of the foundation pit. In order to make the surrounding soil surface settlement and groundwater level meet the requirements of the design specifications, a steel ruler water level gauge SWJ-90-50 recording foundation was arranged between adjacent pumping wells along the length of the foundation pit. During the dewatering process, the water level near the pumping well fluctuated. Trimble DiNi03 electronic level was set at a vertical interval of $5 \mathrm{~m}$ along the center line of the foundation pit to measure surface subsidence (see Table 1); at the same time, inspections of surface subsidence were carried out on building 1, building 2 , and building 3 . The layout map of various measuring points is given in Figure 3.

There were many monitoring points on the site, represented by DB-1, JCJ-6, JCJ-9, and JCJ-15 observation points. The ground surface settlement values of the DB-1, JCJ-6, JCJ-9, and JCJ-15 settlement monitoring groups were selected to display the effect of the deep foundation excavation process on the control of surrounding environment deformation (see Figure 4). The settlement of each measuring point gradually increased over time, and the settlement rate reached its maximum 25 days prior to construction. The settlement values measured at the nearest monitoring point (DB-1) to the foundation pit were the largest value. The results of the other three monitoring points showed the similar flat trends of the settlement values. The greater the self-weight stress of the building next to the monitoring point was, the greater the monitored settlement values were.

\section{Settlement Estimation}

3.1. Settlement Estimation by Analytical Formulas. During the construction of deep foundation pits below the water table, in order to prevent damages such as foundation pit collapse and surge in the pit, the groundwater level should be lowered to $0.5 \mathrm{~m}$ below the bottom of the foundation pit before construction.

A cone of depression was formed which caused decrease of groundwater pressure between soils and increase in effective stress between soil particles. In the process of foundation pit dewatering, groundwater moves slowly in laminar flow, and the dewatering curve is distributed symmetrically along the pumping well. Dupuit formula is introduced as the dewatering depression curve equation as follows [19]:

$$
y^{2}=(l+h)^{2}+\left[H^{2}-(l+h)^{2}\right] \frac{\ln (x / r)}{\ln (R / r)},
$$

where $x$ is the horizontal distance from the center of the well axis; $l$ is the length of the water filter pipe of the dewatering well; $r$ is the radius of the pumping well; $h$ is the vertical distance from the partially penetrating well to the aquifer; and the full penetrating well $h=0$, and the radius of dewatering influence is $R$.

During the dewatering process, there is air inside the unsaturated zone, and the pore water will be tensioned. The balanced differential equation and stress differential equation of the soil particles and pore water can be combined to 

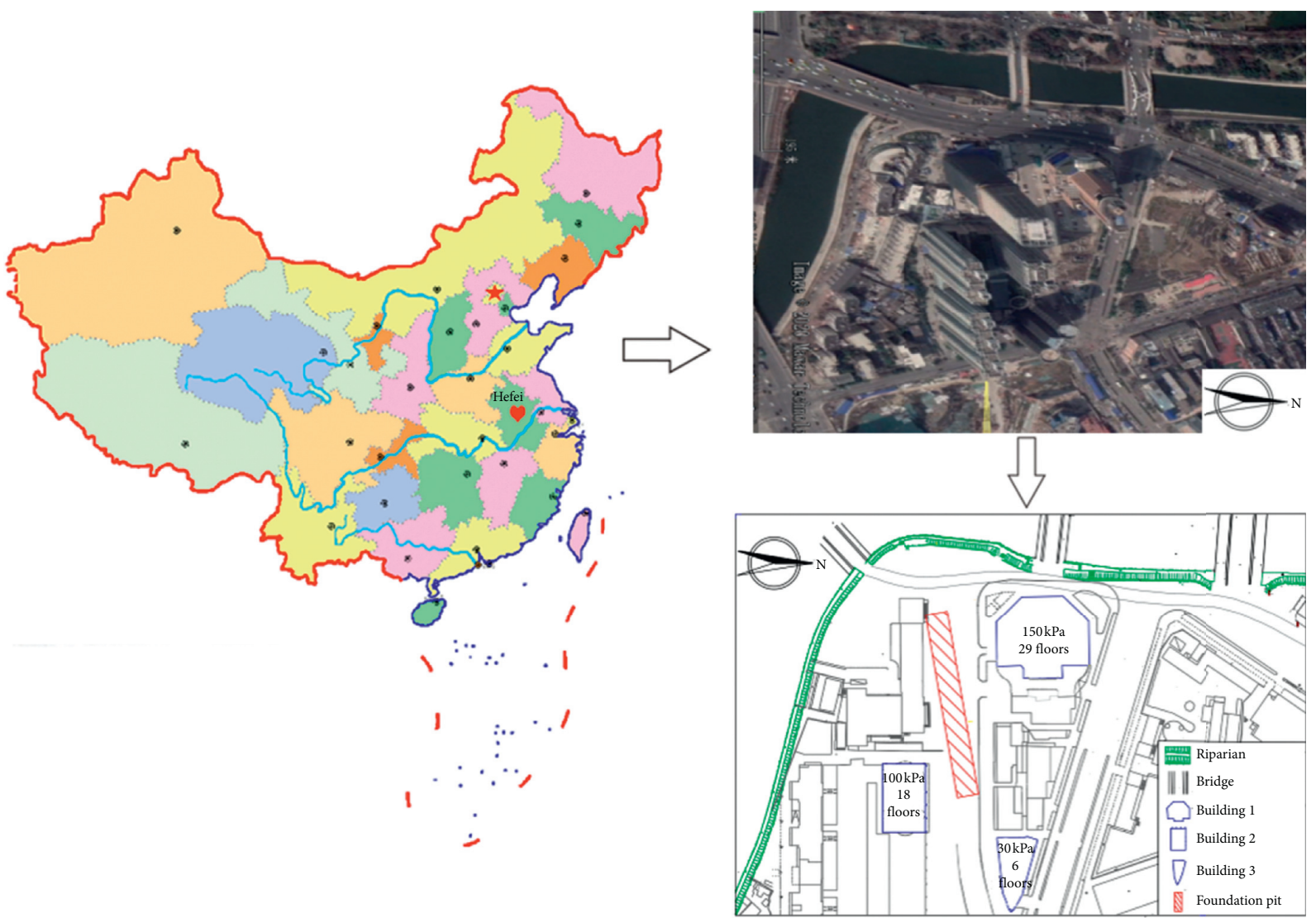

Figure 1: The location of the project site.

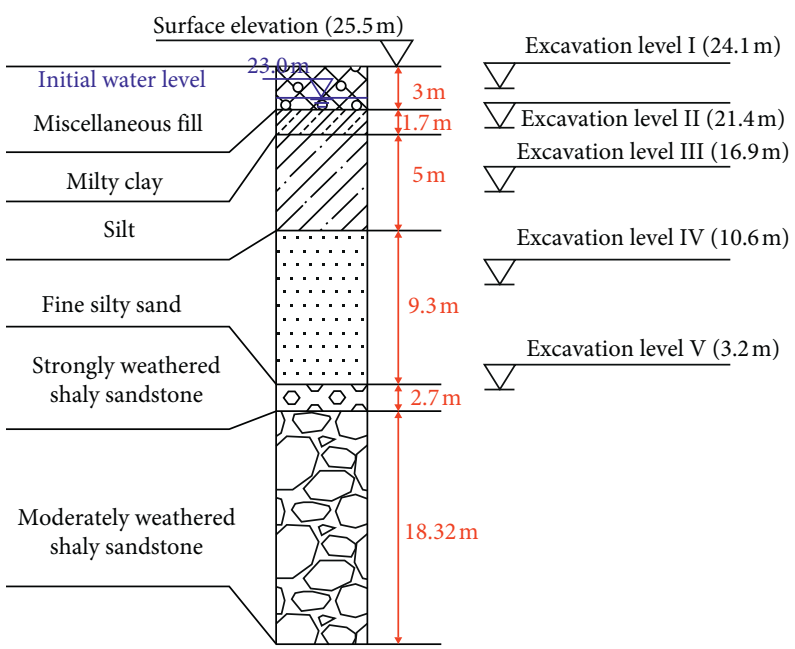

Figure 2: Detailed geological profile of the site.

obtain a unified effective stress equation applicable to unsaturated soil and saturated soil [20]:

$$
\begin{aligned}
& \sigma^{\prime}=\left(\sigma-u_{a}\right)+S_{\mathrm{e}}\left(u_{a}-u_{w}\right), \\
& S_{\mathrm{e}}=\frac{\left(S-S_{\mathrm{r}}\right)}{\left(1-S_{\mathrm{r}}\right)}=\frac{\left(\theta-\theta_{\mathrm{r}}\right)}{\left(\theta_{\mathrm{s}}-\theta_{\mathrm{r}}\right)} \\
& \tau=u_{a}-u_{w} .
\end{aligned}
$$

In the formula, $S_{\mathrm{e}}$ and $S_{\mathrm{r}}$ are the effective saturation and residual saturation of the soil, respectively; $\theta_{s}$ and $\theta_{\mathrm{r}}$ are the saturated volumetric water content and residual volumetric water content, respectively; $\tau$ is the matrix suction, measured by unsaturated soil triaxial apparatus and pressure plate instrument. When the effective volume saturation $S_{\mathrm{e}}$ is equal to 1 , the equation returns to the effective stress equation of saturated soil. 
TABLE 1: Monitoring equipments.

\begin{tabular}{lcccc}
\hline Number & Monitor items & Equipment & Measuring accuracy $(\mathrm{mm})$ & Frequency \\
\hline 1 & Surface settlement & Trimble DiNi03 & 1.0 & Once/3 days \\
2 & Groundwater level & SWJ-90-50 & 5.0 & Once $/ 3$ days \\
3 & Building settlement & Trimble DiNi03 & 1.0 & Once/3 days \\
\hline
\end{tabular}

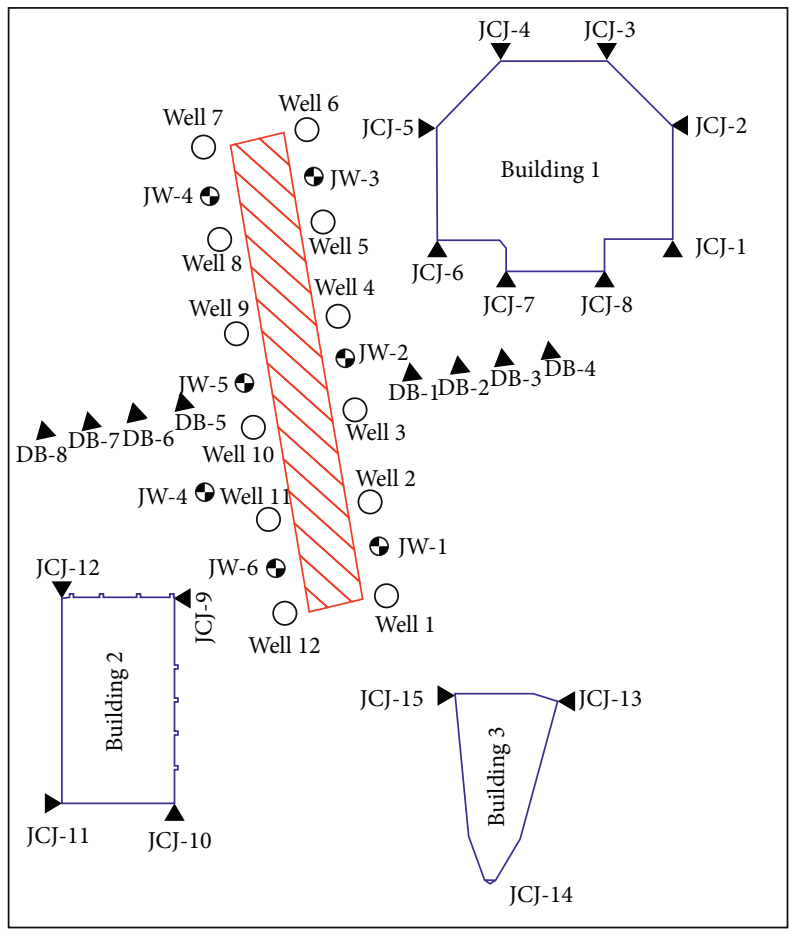

Pumping well

$\ominus$ Water level gauge

Alectronic level

FIGURE 3: Monitoring point layout map.

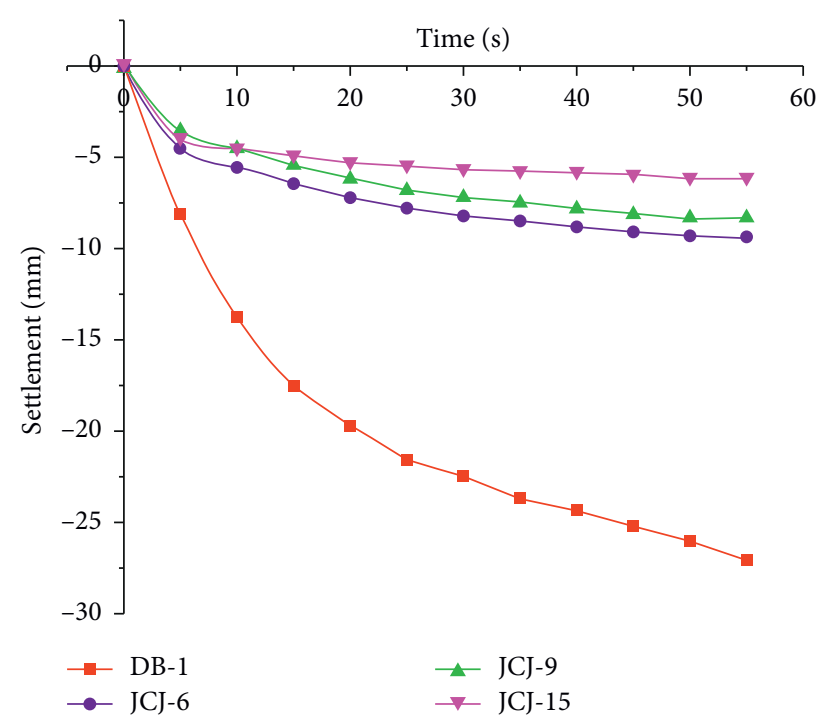

FIgURE 4: Settlement values of monitoring points. 
TABLE 2: The physical and mechanical parameters of the soil layer.

\begin{tabular}{|c|c|c|c|c|c|c|}
\hline Name & $\begin{array}{c}\text { Thickness } H \\
(\mathrm{~m})\end{array}$ & $\begin{array}{c}\text { Elastic modulus } E \\
(\mathrm{MPa})\end{array}$ & $\begin{array}{c}\text { Cohesion } c \\
(\mathrm{kPa})\end{array}$ & $\begin{array}{c}\text { Friction angle } \\
\varphi\left({ }^{\circ}\right)\end{array}$ & $\begin{array}{l}\text { Poisson's } \\
\text { ratio } v\end{array}$ & $\begin{array}{c}\text { Permeability } k \\
(\mathrm{~m} / \mathrm{d})\end{array}$ \\
\hline Miscellaneous fill & 3.1 & 8 & 15 & 10 & - & 0.05 \\
\hline Silty clay & 1.7 & 12 & 10 & 24 & 0.35 & 0.01 \\
\hline Silt & 5 & 10 & - & - & 0.3 & 1 \\
\hline $\begin{array}{l}\text { Strongly weathered argillaceous } \\
\text { sandstone }\end{array}$ & 2.7 & 53 & 50 & 26 & 0.24 & 1 \\
\hline $\begin{array}{l}\text { Moderately weathered } \\
\text { argillaceous sandstone }\end{array}$ & - & 50 & 130 & 33 & 0.23 & 1 \\
\hline
\end{tabular}

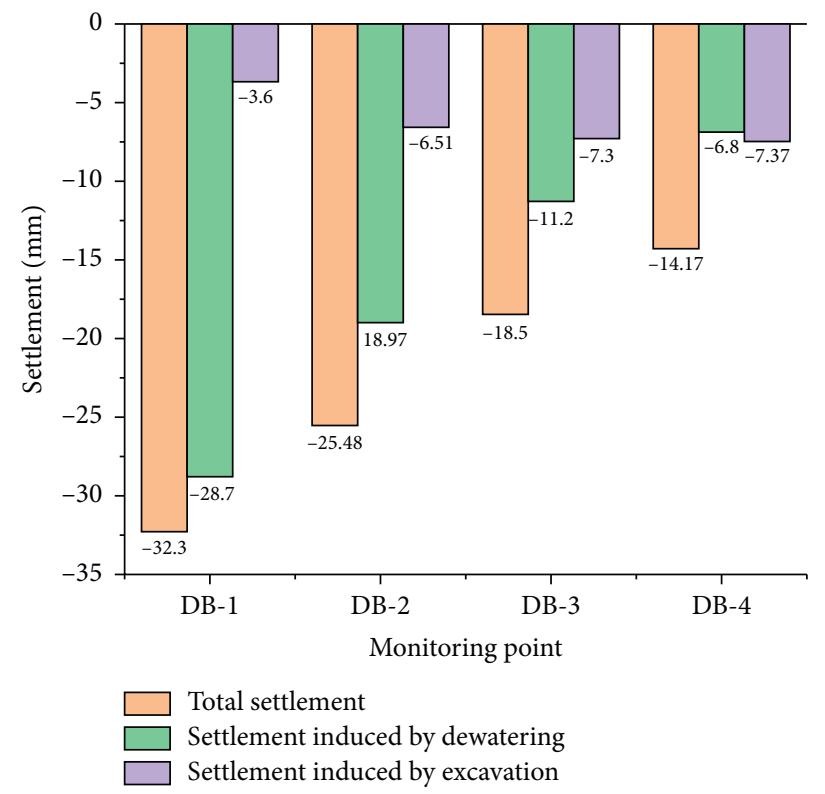

FIgURE 5: Theoretical calculation of surface settlement.

Effective soil stress in the area above the water level did not change before excavation, and the effective stress of the soil in the unsaturated area changed as follows:

$$
\Delta \sigma_{1}^{\prime}=\gamma_{w}(H-y)+\left(S_{\mathrm{e}}-1\right) \tau .
$$

For saturated soil, the pores between soil particles are completely filled with water, and the drop of groundwater level causes the pore water pressure decreasing. The equation returns to the saturated soil effective stress equation, and the effective stress change value is the water pressure decrease:

$$
\Delta \sigma_{2}^{\prime}=\gamma_{w}(H-y) .
$$

Surface settlements caused by dewatering can be calculated by the layerwise summation method as follows:

$$
s=\sum_{i=1}^{n} s_{i}=\sum_{i=1}^{n} \frac{\Delta \sigma_{i}^{\prime}}{E_{i}} h_{i} .
$$

In the formula, $s$ is the surface settlements which caused dewatering; $s_{i}$ is the surface settlements of layer $i ; E_{i}$ is the soil elastic modulus of layer $i$; and $h_{i}$ is the thickness of layer $i$.
According to the layerwise summation formula, the effective stress of the soil in the dry soil area has not changed, so in dry soil, area $s_{1}=0$.

Settlement of the soil layer in the unsaturated zone is as follows:

$$
s_{2}=\sum_{i=1}^{n} \frac{\gamma_{w}(H-y)+\tau\left(S_{\mathrm{e}}-1\right)}{E_{i}} h_{i} .
$$

Settlement of soil layer in saturated zone is as follows:

$$
s_{3}=\sum_{i=1}^{n} \frac{\gamma_{w}(H-y)}{E_{i}} h_{i} .
$$

The excavation of the foundation pit leads to soil unloading which breaks the balance of the self-weight stress in the excavation area and ground settlement. According to the empirical formula formed by the Rayleigh distribution function, the amount of ground settlement caused by foundation pit excavation is calculated as follows [8]: 


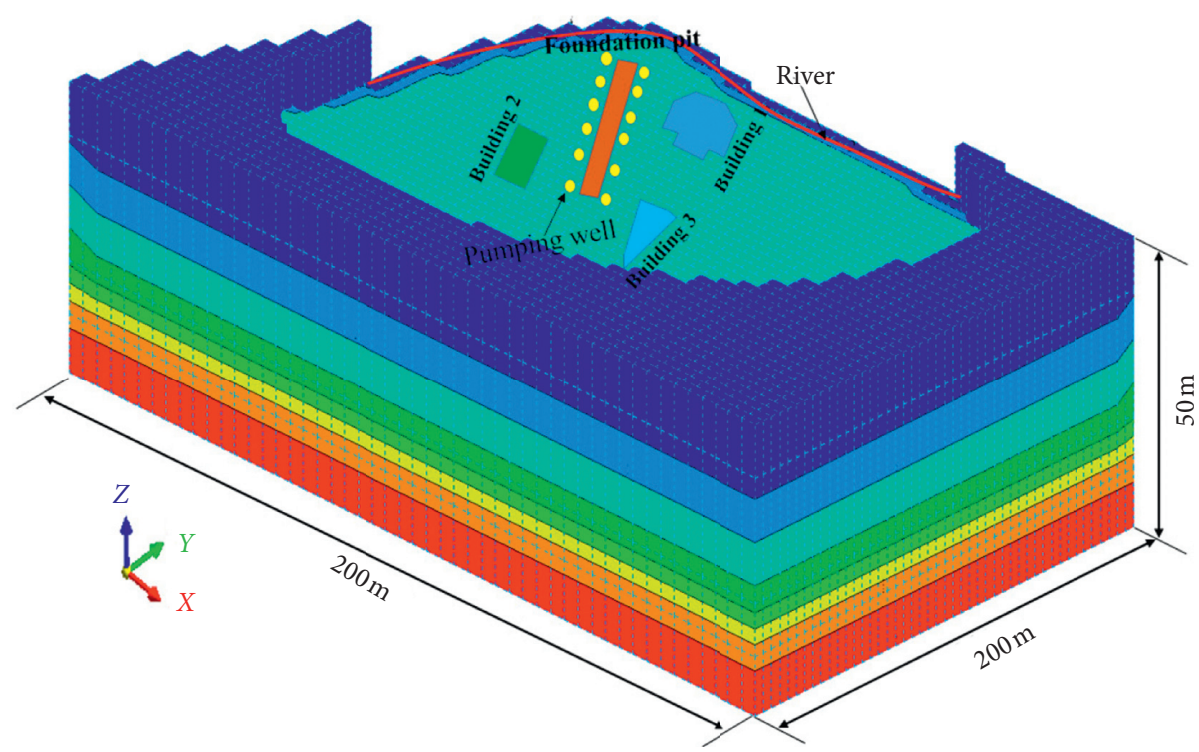

(a)

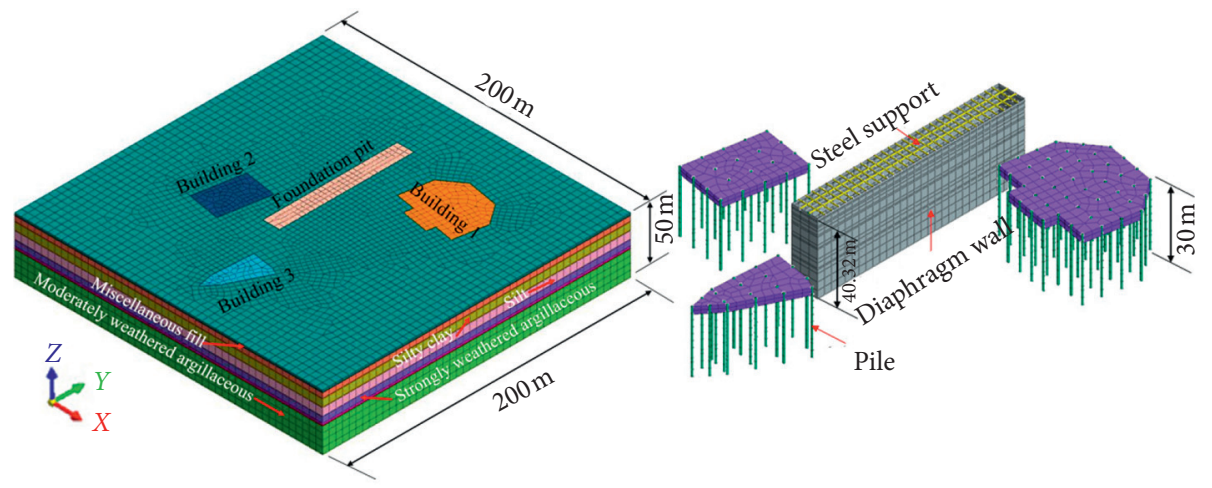

(b)

Figure 6: Meshing of numerical models.

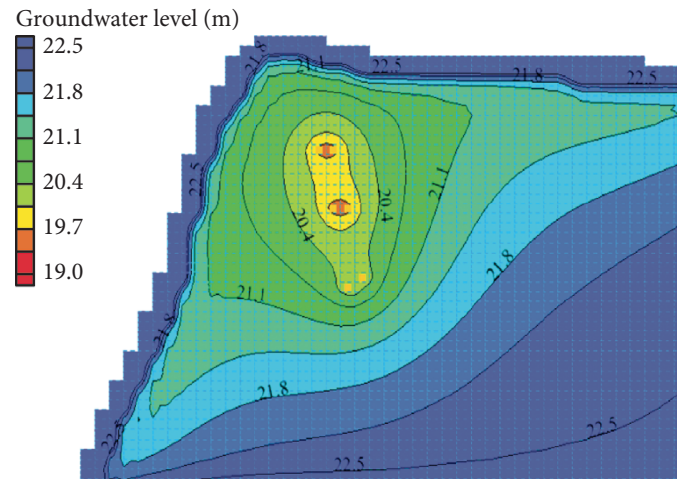

(a)

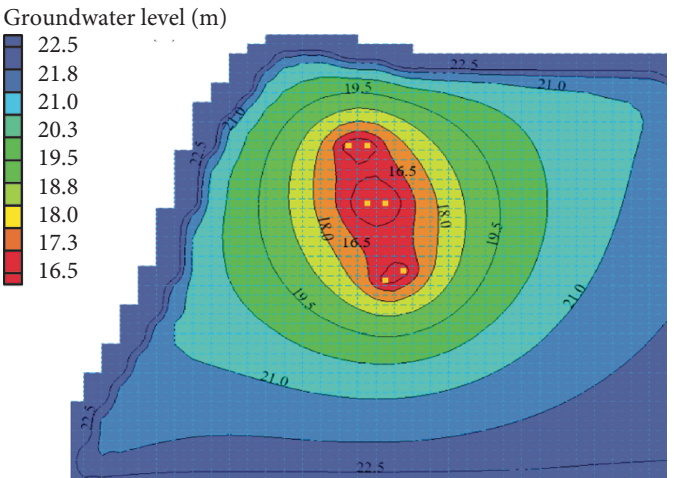

(b)

Figure 7: Continued. 


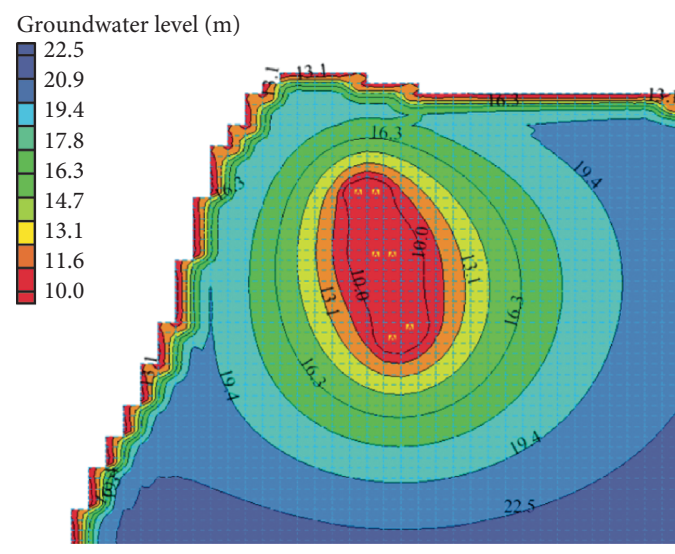

(c)

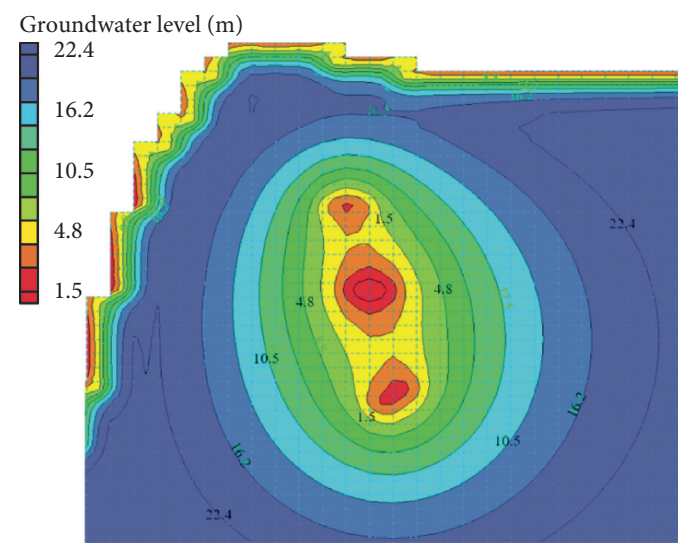

(d)

FIGURE 7: Contours of groundwater level after each dewatering stage. (a) After the first stage of dewatering. (b) After the second stage of dewatering. (c) After the third stage of dewatering. (d) After the fourth stage of dewatering.

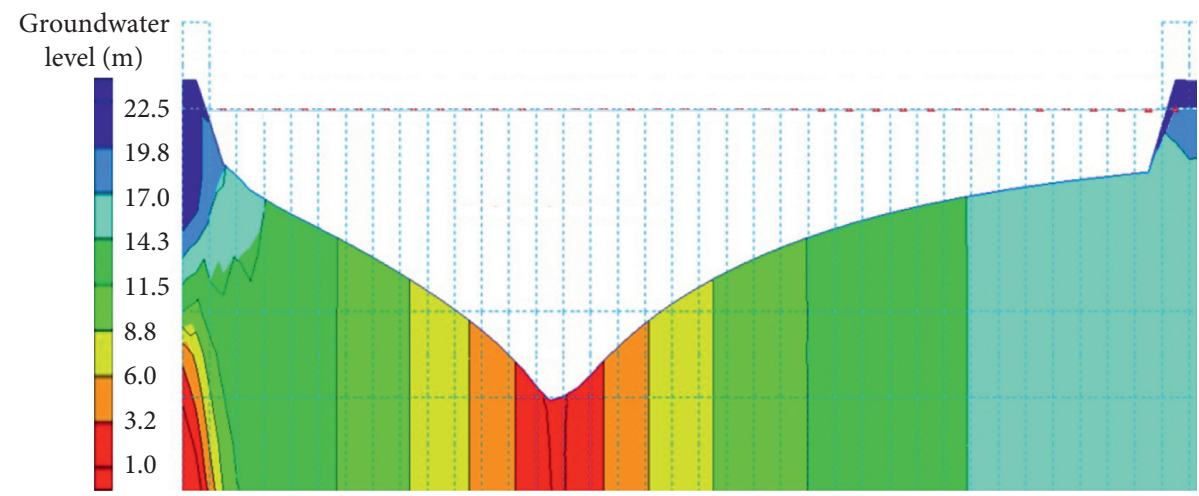

FIGURE 8: The profile of the groundwater table after the fourth dewatering stage.

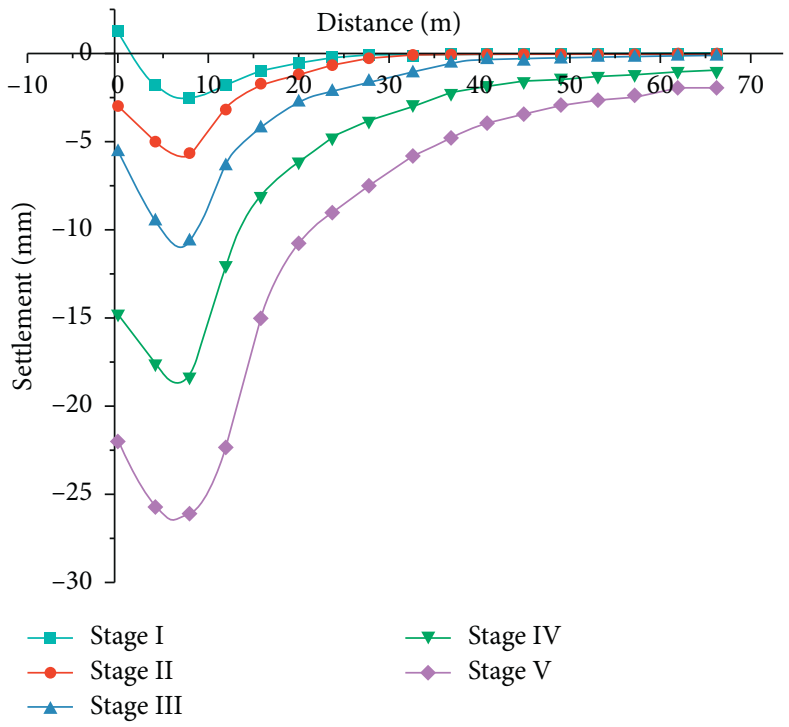

FIgURE 9: Surface settlement curve. 


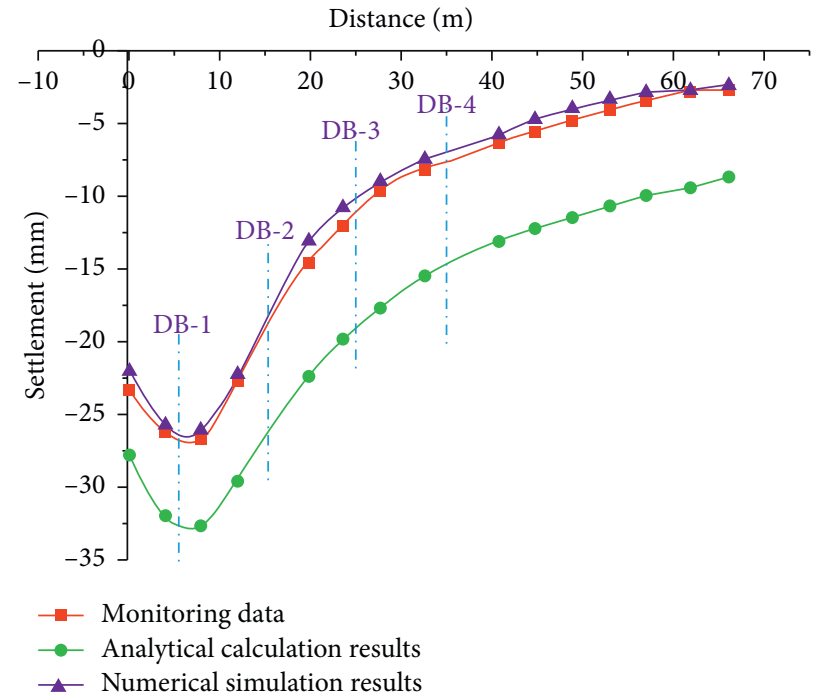

Figure 10: Comparison between different settlement values.

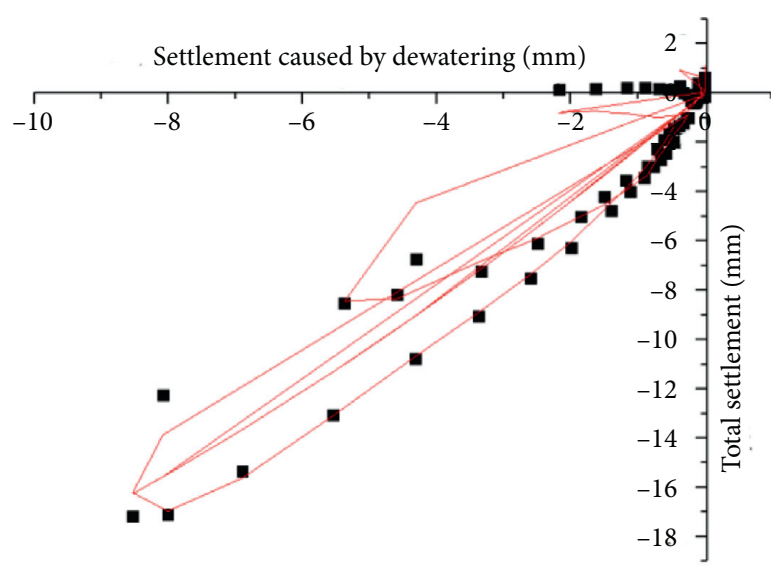

(a)

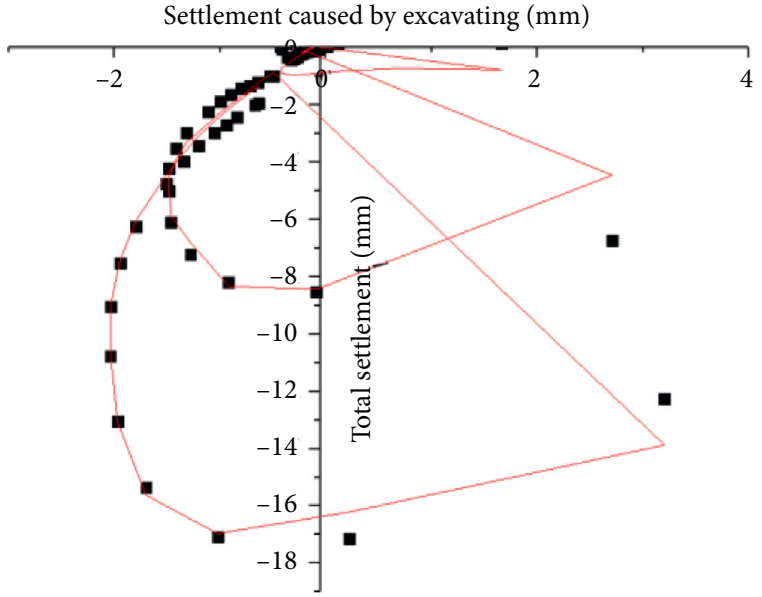

(b)

FIGURE 11: Fitted curve between the total settlement and settlement caused by dewatering and excavation.

$$
\begin{aligned}
s_{4} & =s_{\mathrm{vm}} \cdot \frac{(d / H)+0.75}{0.9} \cdot \exp \left\{-\frac{[(d / H)+0.75]^{2}}{4.5}\right\}, \\
s_{\mathrm{vm}} & =\alpha s_{\mathrm{hm}}, \\
s_{\mathrm{hm}} & =k_{\delta} H,
\end{aligned}
$$

where $d$ is the distance from the excavation point to the center of the foundation pit; $H$ is the excavation depth; $s_{\mathrm{vm}}$ is the maximum settlement of the foundation pit excavation; $s_{\mathrm{hm}}$ is the maximum deformation of the enclosure; $\alpha$ is the empirical coefficient; and $k_{\delta}$ is the proportional coefficient. The two settlements are superimposed and summed to estimate the amount of ground settlement caused by the dewatering and excavation of the foundation pit. And the settlement caused by excavation and dewatering is the sum of the above:

$$
s=s_{1}+s_{2}+s_{3}+s_{4} .
$$

The physical and mechanical parameters of the soil layer are shown in Table 2. The geotechnical parameters were determined by the conventional testing [21-23].

The calculated results by analytical formulas are shown in Figure 5. The DB series of monitoring points are distributed symmetrically along the foundation pit, which can better indicate the law of surface settlement. From Figure 5, dewatering is the major factor triggering the surface settlements. The maximum settlements occurred at DB-1 point, accounting for $88.9 \%$ of the total subsidence. The distances to the foundation pit from DB-1 point to DB-4 point increased. As the monitoring point was farther away from the foundation pit, the slower the decline rate of groundwater level was, the smaller the change of effective stress of soil layer was, resulting in smaller proportion of dewatering contributing to surface settlement. 
3.2. Settlement Estimation by Numerical Models. In this paper, three-dimensional coupling numerical models were established by applying commercial software (GMS and MIDAS) to investigate the interaction impact of excavation and dewatering on the sedimentation deformation (see Figure 6). The width of the river is about $30 \sim 80 \mathrm{~m}$, and the elevation of the river bottom is about $5 \sim 6 \mathrm{~m}$. The calculated parameters adopted the value as shown in Table 2 .

Figure 7 indicates the evolution of groundwater level after each stage of dewatering. In the dewatering process, the groundwater level was distributed in a funnel shape with the dewatering well near the foundation pit as the center. The farther the distance from the center of the foundation pit is, the smaller the drop of groundwater level is (see Figure 8).

Figure 9 shows the simulated surface settlements at each excavation stage. During the first excavation of the foundation pit, the excavation depth was $1.4 \mathrm{~m}$, and the supporting structure was not completed at this time. Due to the unloading effect of the soil, the foundation was uplifted. The settlement curve is distributed as a "spoon" shape from the horizontal distance of the excavation center of the foundation pit. The settlement value increased with the increase of distance from the foundation pit at the distance ranging from 0 to $8 \mathrm{~m}$. However, the values of settlement decreased with the increase of distance from the foundation pit when the distance was greater than $8 \mathrm{~m}$. The accumulated settlement of five excavations reaches the maximum at the fifth stage of excavation, which is $26.1 \mathrm{~mm}$.

3.3. Comparison of Results between Calculated Results and Settlement Monitoring Data. Figure 10 shows the comparison between calculated results and settlement monitoring data. The numerical simulation results obtained from a fluidsolid coupling model matched well with the monitoring data than the analytical calculation results, which suggested that the impact of excavation and dewatering on surface settlement cannot simply be added together. As the groundwater level dropped, the effective stress in the soil increased which changed the porosity of the soil and indirectly changed the state of water movement. However, the analytical calculation method directly superimposes the settlement caused by dewatering and excavation, which did not consider the interaction between water and soil leading to the larger result than the monitored data.

\section{Discussion and Conclusions}

This paper used analytical formulas and numerical models to simulate surface settlements of a deep foundation pit of a metro station aimed at investigating the interaction response to surface settlement of deep foundation and dewatering. The conclusions are as follows:

(1) The ground settlement caused by the construction of the foundation pit was distributed as a "spoon" shape centered on the foundation pit, which is proportional to the depth of the excavation. At a distance of $6.1 \mathrm{~m}$ from the center of the foundation pit, the settlement reached the maximum value of $26.1 \mathrm{~mm}$.
Analytical calculation results showed that the surface subsidence is mainly caused by dewatering. As the distance from the monitoring location to the center of the foundation pit was getting further, the lower the groundwater level falls, the smaller the effective stress change of the soil layer, which decreases the influence contribution of dewatering to the surface settlement.

(2) The numerical simulation results obtained from a fluid-solid coupling model matched well with the monitoring data than the analytical calculation results, which suggested that the impact of excavation and dewatering on surface settlement cannot simply be lineally added together. Therefore, an empirical surface subsidence correlations equation was developed by the polynomial fitting to illustrate the effect contribution on the total surface settlement of foundation excavation and dewatering (as shown in Figure 11). The total settlement can be expressed by dewatering settlement and excavation settlement as follows:

$$
z=-0.08 x^{2}+0.93 x+0.01 y^{2}+1.101 y+0.015
$$

where $z$ represents the total settlement value, $x$ is the settlement caused by dewatering, and $y$ is the excavation settlement; the value of $R^{2}$ after fitting adjustment is 0.999 , so the fitted equation can be considered accurate.

\section{Data Availability}

The data of numerical results used to support the findings of this study can be obtained from the corresponding author upon request.

\section{Conflicts of Interest}

The authors declare that they have no conflicts of interest.

\section{Acknowledgments}

This research work was funded by the National Natural Science Foundation of China (51774107 and 42077249), the Open Program of State Key Laboratory of Explosion Science and Technology, Beijing Institute of Technology (KFJJ1902M), and the Fundamental Research Funds of the Housing and Construction Department of Anhui Province (2013YF27).

\section{References}

[1] J. H. Kihm, J. M. Kim et al., "Three-dimensional numerical simulation of fully coupled groundwater flow and land deformation due to groundwater pumping in an unsaturated fluvial aquifer system," Journal of Hydrology, vol. 335, no. 1-2, pp. 1-14, 2007.

[2] C. C. Faunt, M. J. Sneed, and J. T. Brandt, "Water availability and land subsidence in the Central Valley, California, USA," Hydrogeology Journal, vol. 24, no. 3, pp. 675-684, 2016. 
[3] M. Traum and I. Adiyaman, "The influence of clay zones on land subsidence from groundwater pumping," Ground Water, vol. 51, no. 1, pp. 51-57, 2013.

[4] D. L. Galloway and T. J. Burbey, "Review: regional land subsidence accompanying groundwater extraction," Hydrogeology Journal, vol. 19, no. 8, pp. 1459-1486, 2011.

[5] C. R. Jesús, "Settlements around pumping wells: analysis of influential factors and a simple calculation procedure," Journal of Hydrology, vol. 548, pp. 225-236, 2018.

[6] D. Roy and K. E. Robinson, "Surface settlements at a soft soil site due to bedrock dewatering," Engineering Geology, vol. 107, no. 3-4, pp. 109-117, 2009.

[7] E. Pujades, E. Vàzquez-Suñé, J. Carrera, and A. Jurado, "Dewatering of a deep excavation undertaken in a layered soil," Engineering Geology, vol. 178, pp. 15-27, 2014.

[8] R. B. Peck, "Deep excavations and tunneling in soft ground," in Proceedings of the 7th International Conference on Soil Mechanics and Foundation Engineering, Scientific Research Publishing, Mexico, USA, August 1969.

[9] E. H. Y. Leung and C. W. W. Ng, "Wall and ground movements associated with deep excavations supported by cast in situ wall in mixed ground conditions," Journal of Geotechnical and Geoenvironmental Engineering, vol. 133, no. 2, pp. 129-143, 2007.

[10] P. Guo and X. Gong, "Displacement and force analyses of braced structure of deep excavation considering unsymmetrical surcharge effect," Computers and Geotechnics, vol. 113, pp. 103-102, 2019.

[11] H. Di, H. Guo, S. Zhou, J. Chen, and L. Wen, "Investigation of the axial force compensation and deformation control effect of servo steel struts in a deep foundation pit excavation in soft clay," Advances in Civil Engineering, vol. 2019, no. 6, 16 pages, Article ID 5476354, 2019.

[12] M. Budhu and I. B. Adiyaman, "Mechanics of land subsidence due to groundwater pumping," International Journal for Numerical and Analytical Methods in Geomechanics, vol. 34, no. 14, pp. 1459-1478, 2010.

[13] J. C. Ni, W. C. Cheng, and L. Ge, "A case history of field pumping tests in a deep gravel formation in the Taipei Basin, Taiwan," Engineering Geology, vol. 117, no. 1-2, pp. 17-28, 2011.

[14] H. A. Loáiciga, "Consolidation settlement in aquifers caused by pumping," Journal of Geotechnical and Geoenvironmental Engineering, vol. 139, no. 7, pp. 1191-1204, 2013.

[15] J. Pacheco-Martínez, M. Hernandez-Marín, T. J. Burbey et al., "Land subsidence and ground failure associated to groundwater exploitation in the Aguascalientes Valley, México," Engineering Geology, vol. 164, pp. 172-186, 2013.

[16] A. Jayeoba, S. A. Mathias, S. Nielsen, V. Vilarrasa, and T. I. Bjørnarå, "Closed-form equation for subsidence due to fluid production from a cylindrical confined aquifer," Journal of Hydrology, vol. 573, pp. 964-969, 2019.

[17] C. W. W. Ng, Y. Hong, G. B. Liu, and T. Liu, "Ground deformations and soil-structure interaction of a multi-propped excavation in Shanghai soft clays," Géotechnique, vol. 62, no. 10, pp. 907-921, 2012.

[18] Y. M. A. Hashash, A. Osouli, and C. Marulanda, "Central artery/tunnel project excavation induced ground deformations," Journal of Geotechnical and Geoenvironmental Engineering, vol. 134, no. 9, pp. 1399-1406, 2008.

[19] J. Bear, Hydraulics of Groundwater, Vol. 5, McGraw-Hill International Book, New York, NY, USA, 1979.

[20] S. Longtan, Q. Yalong, G. Xiaoxia et al., "The validation of the effective stress principle of unsaturated soils," Chinese Journal of Underground Space and Engineering, vol. 14, no. 6, pp. 1476-1483, 2018.

[21] S. D. Mohammadi, M. R. Nikoudel, H. Rahimi, and M. Khamehchiyan, "Application of the dynamic cone penetrometer (DCP) for determination of the engineering parameters of sandy soils," Engineering Geology, vol. 101, no. 3-4, pp. 195-203, 2008.

[22] M. Wang and W. Wan, "A new empirical formula for evaluating uniaxial compressive strength using the Schmidt hammer test," International Journal of Rock Mechanics and Mining Sciences, vol. 123, Article ID 104094, 2019.

[23] M. Wang, W. Wan, and Y. Zhao, "Experimental study on crack propagation and the coalescence of rock-like materials with two preexisting fissures under biaxial compression," Bulletin of Engineering Geology and the Environment, vol. 79, no. 6, pp. 3121-3144, 2020. 